\title{
Hubungan antara Kemampuan Self-Regulated Learning dengan Flow Experience Perkuliahan Daring Selama Masa Pandemi Covid-19
}

\author{
ELKANITA DWI KRISWANTI \& ENDAH MASTUTI* \\ Fakultas Psikologi Universitas Airlangga
}

\begin{abstract}
ABSTRAK
Adanya pandemi Coronavirus-19 (COVID-19) di Indonesia berdampak pada penerapan kebijakan perkuliahan daring di perguruan tinggi. Penelitian ini bertujuan untuk mengetahui hubungan antara kemampuan self-regulated learning dengan flow experience mahasiswa yang melaksanakan perkuliahan daring selama masa pandemi. Penelitian ini merupakan penelitian kuantitatif dengan menggunakan metode survei. Penelitian ini melibatkan 252 mahasiswa strata satu sebagai partisipan. Instrumen penelitian yang digunakan adalah skala Motivated Strategies for Learning Questionnaire (MSLQ) dengan skala Flow in education scale (EduFlow-2). Hasil penelitian menunjukkan terdapat hubungan yang signifikan antara kemampuan self-regulated learning dengan flow experience perkuliahan daring pada mahasiswa. Hal ini menunjukkan semakin tinggi kemampuan self-regulated learning yang dimiliki mahasiswa maka semakin tinggi juga mahasiswa mengalami flow experience selama melaksanakan aktivitas perkuliahan daring.
\end{abstract}

Kata kunci: flow experience, mahasiswa, perkuliahan daring, self-regulated learning

\section{ABSTRACT}

Coronavirus-19 (COVID-19) pandemic in Indonesia has an impact on the policy of distance learning in higher education. This research aims to determine the relationship between self-regulated learning and flow experience in distance learning on college student during the pandemic. This research is quantitative research, using a survey method. This study involved 252 undergraduate students as participant. The instrument tools used were the Motivated Strategies for Learning Questionnaire (MSLQ) and Flow in Education Scale (EduFlow-2). The results showed that there is a significant relationship between self-regulated learning with flow experience in distance learning on college student. It means that the higher self-regulated learning, will be followed by the higher flow experience in distance learning on college student.

Keywords: college student, distance learning, flow experience, self-regulated learning

Buletin Penelitian Psikologi dan Kesehatan Mental (BRPKM), 2021, Vol. 1(1), 746-755

*Alamat korespondensi: Fakultas Psikologi Universitas Airlangga, Kampus B Universitas Airlangga Jalan Airlangga 4-6 Surabaya 60286. Surel: endah.mastuti@psikologi.unair.ac.id 


\section{PEN D A H U L U A N}

Pandemi COVID-19 yang terjadi sejak awal tahun 2020 telah ditetapkan sebagai Bencana Nasional oleh pemerintah Indonesia (Kementerian Sekretariat Negara RI, 2020). Pemerintah mengeluarkan berbagai kebijakan sebagai langkah pencegahan penyebaran dan penularan virus, salah satunya adalah penerapan perkuliahan daring di seluruh perguruan tinggi. Menurut Simonson dkk (2015) perkuliahan daring adalah pendidikan formal dimana kelompok pembelajaran dipisahkan dan sistem telekomunikasi interaktif digunakan untuk menghubungkan mahasiswa, dosen dan sumber daya materi. Perkuliahan daring sendiri telah dijelaskan dalam Undang-Undang no 12 tahun 2012, yaitu proses belajar mengajar yang dilakukan secara jara jauh melalui penggunaan berbagai media komunikasi (Kementerian Sekretariat Negara RI, 2012).

Fakultas Psikologi Universitas Airlangga merupakan salah satu institusi yang melakukan transisi perkuliahan daring dari rumah. Perubahan ini tidak memerlukan persiapan yang banyak pada institusi. Fakultas Psikologi Universitas Airlangga sudah memiliki bekal sistem dan pengajar yang baik saat adanya peralihan perkuliahan daring yang ditetapkan oleh Kementerian Pendidikan dan Kebudayaan Republik Indonesia. Sebelum adanya pandemi Covid-19 Fakultas Psikologi Universitas Airlangga sudah menerapkan metode pembelajaran blended learning menggunakan bantuan situs web bernama PsyCHE (Psychology Classroom Hybrid Education). Model pembelajaran berupa flipped classroom dimana aktivitas belajar mahasiswa dilakukan secara tatap muka di dalam kelas dan juga secara daring di luar kelas (Staker \& Horn, 2012). Sebelum mengikuti kelas tatap muka di dalam kelas, mahasiswa belajar dan mengerjakan tugas sesuai dengan rancangan pembelajaran yang diberikan oleh dosen secara daring. Setelah adanya adaptasi pandemi Covid-19, Fakultas Psikologi Universitas Airlangga menggunakan metode pembelajaran secara daring yang dapat dilaksanakan secara synchronous dan asynchronous. Metode pembelajaran dilakukan dengan prinsip DIA yakni adanya aspek content delivery, interaction and assessment dan melakukan melalui beberapa media seperti learning management system, email, social media dan lain-lain (Fakultas Psikologi Universitas Airlangga, 2020).

Pada pelaksanaannya, adanya keterbatasan jarak dan komunikasi antara dosen dan mahasiswa menjadi tantangan belajar tersendiri. Salah satu tantangan dari desain perkuliahan daring adalah untuk melibatkan mahasiswa dan mempertahankan minat dan pikiran mereka pada tugas yang ada (Guo dkk., 2012; Pearce, 2005; Shin, 2006). Beberapa penelitian (Firman \& Rahayu, 2020; Patricia AguileraHermida, 2020) mengungkapkan mahasiswa belum tentu terlibat dan konsentrasi selama proses perkuliahan daring selama masa pandemi COVID-19. Hal ini disebabkan oleh beberapa faktor antara lain pertama, belajar di rumah lebih banyak distraksi yang dialami dibandingkan di dalam kelas seperti gangguan dari anggota keluarga, gangguan sinyal, kebisingan, atau pekerjaan rumah. Kedua, terlalu lama menatap layar gawai membuat mata mereka cepat lelah. Ketiga, terlalu lama belajar di rumah membuat mereka kehilangan motivasi belajar dan menimbulkan emosi negatif. Hal serupa juga dialami oleh mahasiswa Fakultas Psikologi Universitas Airlangga. Hasil dari studi pendahuluan yang dilakukan melalui wawancara dan angket kepada 14 mahasiswa adalah mahasiswa mengaku sulit untuk fokus selama melakukan perkuliahan daring dengan alasan lima mahasiswa kesulitan menemukan tempat yang nyaman untuk belajar, empat mahasiswa merasa mengantuk, tiga mahasiswa merasa malas, satu mahasiswa mengaku mengerjakan tugas lain dan satu mahasiswa mengaku bosan. Artikel ini melaporkan penelitian dimana kami mengeksplorasi pengalaman mahasiswa yang terlibat dalam tugas yang disebut dengan flow experience (Csikszentmihalyi, 2014).

Flow experience merupakan pengalaman emosional belajar yang positif yang dapat membantu mahasiswa membenamkan diri dalam pembelajaran, melupakan perjalanan waktu dan mengejar nilai 
dari pembelajaran itu sendiri (Csikszentmihalyi, 2014). Mahasiswa yang sedang mengalami flow experience, dia dalam keadaan konsentrasi yang sangat terfokus sehingga mencapai penyerapan absolut dan juga akan memunculkan kesejahteraan bagi dirinya sehingga dia menikmati aktivitas yang sedang dilakukannya. Mahasiswa akan bersedia melakukan kegiatan tersebut dalam waktu yang lama serta melibatkan diri secara keseluruhan karena adanya keinginan dari diri sendiri untuk terus dapat merasakan kesenangan tersebut (Csikszentmihalyi, 2014).

Flow experience terjadi ketika tantangan dan keterampilan yang dirasakan seimbang dan tinggi (Csikszentmihalyi, 2014). Ketika tantangan belajarnya jauh lebih tinggi daripada kemampuan yang dimiliki daripada kapasitas mahasiswa tersebut, maka mahasiswa akan cenderung mengalami kecemasan. Saat situasi sebaliknya, yaitu mahasiswa memiliki kemampuan yang lebih tinggi dibandingkan tantangan yang dihadapi atau kurangnya kesempatan untuk mengekspresikan kemampuannya, maka mahasiswa cenderung akan merasa bosan dalam proses belajar. Dan flow experience terjadi pada diagonal tersebut, dimana adanya rasio seimbang antara tantangan yang dihadapi dan keterampilan yang dimiliki oleh mahasiswa.

Sudah banyak penelitian-penelitian tentang flow experience dalam bidang akademik, termasuk perkuliahan daring. Hasil penelitian-penelitian tersebut diketahui adanya flow experience memiliki hubungan positif dengan gaya belajar (Rong \& Min, 2005), desain pembelajaran (Joo dkk., 2014; Wan dkk., 2020) dan karakter diri (Shin, 2006). Selain itu, kemampuan pengendalian diri dalam belajar (selfregulated learning) memiliki hubungan positif dengan flow experience (Joo dkk., 2014; Liao, 2006; Wan dkk., 2020). Perkuliahan daring memiliki karaktersitik student center learning dan kemampuan selfregulated learning menjadi salah satu kunci sukses perkuliahan daring (Barnard dkk., 2009).

Kemampuan pengendalian diri (self-regulated learning) merupakan kemampuan mahasiswa untuk aktif dan konstruktif selama proses pembelajaran dengan menetapkan tujuan dan strategi berusaha untuk memantau, mengelola dan mengendalikan aspek kognisi, motivasi dan perilaku sesuai dengan tujuan dan konteks lingkungan (Pintrich, 2000). Zimmerman (1990) menjelaskan mahasiswa yang sudah menerapkan self-regulated learning dalam proses pembelajarannya tidak lagi bergantung kepada dosen, teman atau orang lain, melainkan berusaha secara mandiri untuk memperoleh pengetahuan dan keterampilan yang dibutuhkan. Mahasiswa juga mampu memantau keefektifan metode atau strategi belajarnya kemudian beradaptasi dengan mengubah pikiran atau lingkungan belajar untuk mengoptimalkan proses pembelajarannya.

Menurut Pintrich (1995) self-regulated learning memiliki empat fase yang mewakili urutan waktu secara umum yang akan dilalui mahasiswa saat mereka dalam proses pembelajaran dan melakukan tugas. Pertama, forethought, planning and activation phase yaitu melibatkan kemampuan perencanaan dan penetapan tujuan serta aktivasi persepsi dan pengetahuan tentang diri, tugas dan konteks dalam proses pembelajaran. Kedua, monitoring phase, fase ini melibatkan berbagai proses pemantauan yang merepresentasikan kesadaran metakognitif dalam berbagai aspek diri, tugas dan konteks pembelajaran. Ketiga, control phase, usaha untuk mengontrol dan mengatur berbagai aspek diri, tugas dan konteks pembelajaran. Dan keempat, reaction and reflection phase, yaitu merepresentasikan berbagai macam reaksi dan refleksi terhadap diri, tugas atau konteks pembelajaran.

Berdasarkan uraian yang telah dijelaskan diatas, kami kemudian tertarik untuk melakukan kajian tentang hubungan antara kemampuan self-regulated learning dengan flow experience perkuliahan daring pada mahasiswa Fakultas Psikologi Universitas Airlangga 


\section{E T O D E}

\section{Desain Penelitian}

Penelitian ini menggunakan pendekatan kuantitatif dan menggunakan teknik pengumpulan data survei. penelitian ini menggunakan pendekatan kuantitatif dan menggunakan teknik pengumpulan data survei. Berdasarkan tujuannya, penelitian ini merupakan penelitian korelasional yaitu untuk mengetahui kekuatan dan arah hubungan yang ada di antara variabel-variabel berdasarkan koefisien korelasi (Azwar, 2017). Melalui penelitian ini, kami ingin mengetahui ada atau tidaknya hubungan antara kemampuan self-regulated learning dengan flow experience yang dialami mahasiswa saat mengikuti perkuliahan daring selama masa pandemi COVID-19.

\section{Partisipan}

Penelitian ini menggunakan teknik pengambilan sampel berupa purposive sampling. Kriteria partisipan adalah mahasiswa angkatan aktif 2018-2020 Fakultas Psikologi Universitas Airlangga, telah/sedang mengikuti perkuliahan daring minimal tiga bulan terakhir dan bersedia mengisi survei penelitian. Partisipan dalam penelitian ini adalah 252 mahasiswa (204 perempuan dan 48 laki-laki). Partisipan tiap angkatan sama rata yaitu masing-masing 84 orang (33,3\%). Terdapat 156 mahasiswa yang menggunakan laptop untuk perkuliahan daring dan 96 menggunakan smartphone.

\section{Pengukuran}

Skala short version dari Motivated Strategies for Learning Questionnaire (MSLQ) yang telah diadaptasi oleh Muasyaroh (2018) yang penelitian ini pakai untuk mengukur kemampuan self-regulated learning mahasiswa. Skala ini memiliki 61 item yang terdiri dari item favorable dan unfavorable. Penilaian skala MSLQ short version ini menggunakan skala Likert dengan 7 pilihan jawaban $1=$ "sangat tidak sesuai", $7=$ "sangat sesuai"). Setelah dianalisis, terdapat enam item yang gugur sehingga total item yang digunakan penelitian ini berjumlah 55 item. Hasil analisis reliabilitas, dapat disimpulkan skala ini memiliki koefisien reliabilitas yang cukup tinggi ( 55 item; $\alpha=.882$ ).

Skala The Flow in Education Scale version 2 (EduFlow-2) yang disusun oleh Heutte dkk (2016) yang penelitian ini pakai untuk mengukur flow experience mahasiswa. Skala ini memiliki 12 item yang terdiri dari item favorable yang memiliki 7 pilihan jawaban (1="sangat tidak sesuai", 7="sangat sesuai". Setelah dilakukan analisis, dapat disimpulkan skala ini memiliki koefisien reliabilitas yang cukup tinggi (10 item; $\alpha=.826$ ).

\section{Analisis Data}

Analisis data yang digunakan dalam penelitian ini adalah uji statistik hubungan atau korelasional. Sebelum melakukan uji korelasi, terlebih dahulu dilakukan uji asumsi. Diketahui bahwa sebaran data dalam penelitian ini tidak normal sehingga teknik statistik yang digunakan adalah teknik statistik nonparametric dengan Spearman's Rho. Perangkat lunak yang digunakan sebagai alat bantu menganalisa data penelitian ini adalah SPSS 25 for Windows.

\section{HAS I L P E N EL I T IAN}

Hasil analisis data uji asumsi berupa uji normalitas diketahui pada variabel kemampuan self-regulated learning memiliki nilai signifikansi $p=0,002$ dan variabel flow experience memiliki nilai signifikansi $p=0,200$, serta uji linearitas dengan nilai signifikansi $p=0,000$. Hasil uji asumsi tersebut menunjukkan

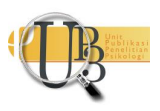


bahwa sebaran data penelitian ini berdistribusi tidak normal dan linear sehingga uji hipotesis menggunakan metode nonparametrik dengan teknik Spearman's Rho. Berdasarkan hasil analisis data uji korelasi diketahui bahwa kemampuan self-regulated learning berkorelasi positif dan cenderung sedang $(r(252)=0,482 ; p=0.000)$ dengan flow experience. Hal ini berarti terdapat hubungan antara kemampuan self-regulated learning dengan flow experience pada mahasiswa dan hipotesis penelitian diterima.

\section{Kategorisasi Hasil Penelitian}

Jawaban mahasiswa tentang kemampuan self-regulated learning tertinggi sebanyak 96 mahasiswa atau $38,10 \%$ masuk dalam kategori sedang. Terdapat 71 mahasiswa atau 28,17\% yang kemampuan selfregulated learning masuk dalam kategori rendah. Terdapat 55 mahasiswa atau 21,83\% yang masuk dalam kategori tinggi, dan 18 mahasiswa atau 7,14\% masuk dalam kategori sangat tinggi. Sebanyak 12 mahasiswa atau 4,76\% masuk dalam kategori sangat rendah. Jadi, dapat disimpulkan bahwa kemampuan self-regulated learning mahasiswa didominasi pada kategori sedang.

Jawaban mahasiswa tentang flow experience yang tertinggi sebanyak 104 mahasiswa atau 41,27\% masuk dalam kategori sedang. Terdapat 58 mahasiswa atau 23,02\% yang flow experience masuk dalam kategori rendah. Terdapat 53 mahasiswa atau 21,03\% yang termasuk dalam kategori tinggi, dan 19 mahasiswa atau 7,54\% termasuk dalam kategori sangat rendah. Sisanya, 18 mahasiswa atau 7,14\% termasuk kategori sangat tinggi. Jadi, dapat disimpulkan bahwa flow experience perkuliahan daring mahasiswa didominasi pada kategori sedang.

\section{I S K U S I}

Berdasarkan hasil analisis data antara variabel kemampuan self-regulated learning dengan flow experience perkuliahan daring, dapat diketahui bahwa kedua variabel tersebut mempunyai hubungan yang positif signifikan. Hal ini menunjukkan bahwa semakin tinggi kemampuan self-regulated learning pada mahasiswa, maka semakin tinggi pula flow experience perkuliahan daring yang dialami mahasiswa. Model flow experience milik Csikszentmihalyi (2014) menjelaskan bahwa parameter terpenting munculnya flow experience adalah adanya keseimbangan antara kemampuan yang dimiliki dengan tantangan yang dihadapi mahasiswa selama proses belajar. Hal ini menunjukkan bahwa kemampuan self-regulated learning sebagai bagian dari keterampilan mahasiswa dalam menyeimbangi tantangan belajar sehingga terjadi flow experience selama proses perkuliahan daring.

Hasil dari penelitian ini sesuai dengan penelitian sebelumnya seperti penelitian yang dilakukan oleh Wan dkk (2020) yang hasil penelitiannya mengungkapkan adanya hubungan yang signifikan antara kemampuan self-regulated learning dengan flow experience mahasiswa yang melakukan perkuliahan daring. Hal serupa juga diungkapkan dari hasil penelitian yang dilakukan oleh (Joo dkk., 2014) bahwa kemampuan self-regulated learning dapat mempengaruhi tingkatan flow experience mahasiswa yang melakukan perkuliahan daring. Joo dkk (2014) menjelaskan mahasiswa yang lebih aktif mengalami flow experience yang tinggi saat mereka mengeksplorasi segala sumber daya dan mengekspresikan kemampuan self-regulated learning yang dimiliki.

Menurut Csikszentmihalyi (2014) adanya kendali dan kebebasan/otonomi yang dimiliki mahasiswa dalam proses belajar akan mempermudah mahasiswa mengalami flow experience. Lingkungan perkuliahan daring yang memiliki karakteristik otonomi dan student-center learning (Simonson dkk., 2015) membuat kemampuan self-regulated learning menjadi faktor penting dalam kesuksesan belajar 
dimana mahasiswa secara mandiri dan proaktif balajar selama perkuliahan daring (Pintrich, 1995). Kemampuan self-regulated learning dapat membantu mahasiswa dalam mengatasi tantangan dan hambatan internal dan eksternal yang dihadapi selama perkuliahan daring. Kemampuan self-regulated learning membuat mahasiswa mampu meregulasi kognisi, motivasi, emosi, perilaku dan lingkungan belajar sesuai dengan tujuan dan konteks yang diinginkan. Regulasi aspek-aspek tersebut akan membantu mempertahankan kondisi konsentrasi mahasiswa selama proses belajarnya. Sementara itu, mahasiswa yang memiliki keterampilan self-regulated learning kurang baik dapat salah menafsirkan otonomi lingkungan belajar daring dan, akibatnya, mungkin tidak menyelesaikan tugas-tugas pembelajaran yang diharapkan dalam kuliah daring (Barnard dkk., 2009).

Fakultas Psikologi memiliki PsyCHE sebagai learning management system. Menurut Firdaus (2018), PsyCHE memiliki reputasi yang bagus dalam penyajian materi kuliah. Secara kontekstual, PsyCHE dinilai sudah lengkap dalam memberikan materi yang diunggah, meliputi kontrak perkuliahan, bahan ajar, artikel, $e$-book, dan soal-soal penunjang. Materi tersebut memberikan pengetahuan tentang gambaran perkuliahan yang akan dihadapi mahasiswa. Mahasiswa menjadi tahu tentang topik, tujuan, metode, jadwal dan tugas apa saja yang ada di dalam mata kuliah tersebut dari kontrak perkuliahan atau RPS. Memanfaatkan sumber daya daring tersebut dapat membantu mahasiswa dalam mengembangkan kemampuan self-regulated learning (Pellas, 2014). Mahasiswa dapat lebih mudah merancang, memonitor, mengontrol dan mengevaluasi proses belajarnya sehingga mereka juga akan lebih mudah untuk menetapkan tujuan belajar, mengatur waktu, membuat strategi belajar dan menciptakan lingkungan belajar yang menyenangkan.

Hubungan antara kemampuan self-regulated learning dengan flow experience mahasiswa di perkuliahan daring dapat dijelaskan melalui empat fase self-regulated learning. Pertama, pada fase forethought, planning and activation dimana dalam fase ini mahasiswa melakukan perencanaan belajar dengan menganalisa kemampuan dan lingkungan serta menetapkan tujuan belajar yang jelas (Pintrich, 2000). Pada fase ini mahasiswa meregulasi motivasi dan afeksinya dengan menetapkan tujuan belajar, ia tahu mengapa ia perlu belajar materi tersebut. Adanya tujuan belajar dapat mentransformasi menjadi kebutuhan dan motivasi mahasiswa untuk belajar (Wan dkk., 2020). Mahasiswa dapat memanfaatkan informasi dari kontrak perkuliahan untuk mengetahui tujuan belajar setiap materi dan pertemuan kuliah. Mahasiswa yang tahu mengapa ia perlu belajar dan pentingnya mempelajari materi tersebut akan membuat mahasiswa menikmati setiap momen belajar sehingga cederung lebih mudah untuk mengalami flow experience (Csikszentmihalyi, 2014).

Pada tahap ini mahasiswa juga mengetahui dan melakukan analisa tentang kemampuan apa saja yang diperlukan dan hambatan apa saja yang dialami, dan selanjutnya mahasiswa membuat rencana strategis untuk mencapai tujuan. Pada tahap ini mahasiswa juga dapat memanfaatkan informasi dari kontrak perkuliahan/RPS dan materi kuliah dari PsyCHE untuk menganalisa dan membuat strategi belajar. Strategi time and study environment dan effort regulation yang baik diperlukan pada tahap ini. Sebagai contoh, ketika mahasiswa melakukan perkuliahan daring mahasiswa memiliki berbagai hambatan, seperti mata cepat lelah melihat layar gawai. Mahasiswa yang memiliki kemampuan self-regulated learning dapat menggunakan strategi regulasi perilaku berupa effort regulation, yaitu dengan setiap 30 menit atau saat mata sudah terasa lelah, mahasiswa mengistirahatkan mata sejenak selama 20 detik dengan menatap hal lain yang jauh. Setelah itu mahasiswa dapat kembali mempehatikan perkuliahan secara fokus kembali.

Kedua, fase monitoring dimana mahasiswa memperhatikan pemahaman atau perkembangan belajar mereka (Pintrich, 2000). Pada fase ini, mahasiswa dapat memantau perilaku, motivasi, dan kognisi mereka sendiri, dan kemudian mengatur dan menyesuaikan karakteristik ini agar sesuai dengan tujuan 
belajar. Selama kondisi flow experience, seluruh perhatian mahasiswa akan terserap sepenuhnya dalam aktivitas belajar (Csikszentmihalyi, 2014). Apabila dalam pertengahan belajar perhatiannya teralihkan atau kurang fokus, mahasiswa yang memiliki kemampuan self-regulated learning yang baik akan segera menyadari hal tersebut kemudian mencoba untuk fokus kembali kepada materi belajar (Pintrich, 1995).

Tahap ketiga, fase control dimana mahasiswa berusaha secara aktif untuk mengatur, memodifikasi, atau mengganti teknik pembelajaran yang sedang dilakukan untuk mempertahankan fokus dan mencapai tujuan belajar (Pintrich, 2000). Apabila dari hasil tahap monitoring ditemukan hambatan dalam proses belajar, seperti materi kuliah yang kurang menarik atau adanya distraksi dari lingkugan maka mahasiswa tersebut akan mencari strategi belajar sehingga ia dapat menikmati proses belajar. Saat kondisi flow, mahasiswa memegang kendali atas tindakan dan lingkungannya (Csikszentmihalyi, 2014). Ia merasa kemampuannya cukup untuk memenuhi tantangan lingkungan.

Tahap keempat, fase reaction and reflection merupakan tahap dimana mahasiswa berusaha meninjau dan mengevaluasi informasi yang dihasilkan dalam fase monitoring untuk membuat penilaian tentang kinerjanya (Pintrich, 2000). Tahap ini juga bisa terjadi ketika akhir proses belajar. Mahasiswa meninjau kembali proses belajarnya sehingga dapat memperbaiki atau mengganti strategi untuk proses belajar selanjutnya lebih menikmati dan konsentrasi (Csikszentmihalyi, 2014).

Menurut penjelasan di atas dapat disimpulkan bahwa ketika mahasiswa memanfaatkan segala sumber daya yang dimiliki dan memiliki kemampuan self-regulated learning, mahasiswa dapat mempertahankan kondisi flow experience mereka selama proses pembelajaran (Liao, 2006).

\section{S I M P U L A N}

Berdasarkan pada analisis dan pembahasan yang dilakukan maka dapat disimpulkan bahwa terdapat hubungan yang signifikan antara kemampuan self-regulated learning dengan flow experience perkuliahan daring pada mahasiswa. Hal ini menunjukkan bahwa semakin tinggi kemampuan selfregulated learning yang dimiliki mahasiswa maka semakin tinggi mahasiswa mengalami flow experience selama aktivitas perkuliahan daring.

Penelitian ini memiliki kekurangan dan keterbatasan dalam pelaksanaannya, antara lain pertama, hasil penelitian ini tidak dapat digeneralisasikan kepada populasi lain karena proses pengambilan data penelitian ini menggunakan teknik purposive sampling. Kedua, penelitian ini menggunakan media daring untuk proses pengambilan data, hal ini menyebabka peneliti tidak dapat menjelaskan secara langsung mengenai kuesioner kepada partisipan sehingga dikhawatirkan adanya perbedaan pemahaman isi item antara persepsi partisipan dengan tujuan penelitian. Ketiga, penelitian ini mengukur pengalaman belajar mahasiswa secara umum di perkuliahan daring Fakultas Psikologi Universitas Airlangga, mahasiswa menilai perkuliahan secara keseluruhan atau memilih perkuliahan yang ia nikmati atau tidak ia nimkati. Flow experience bersifat subjektif sehingga untuk penelitian selanjutnya sebaiknya mempertimbangkan pengalaman belajar dari variasi mata kuliah atau dosen yang dinilai untuk seluruh responden. Penelitian selanjutnya juga dapat mempertimbangkan faktor lain yang mungkin dapat mempengaruhi flow experience di perkuliahan daring, seperti karakteristik pengajar, metode pengajaran dosen, atau sistem teknologi yang digunakan. 


\section{U CAPAN TERIMAKASIH}

Terima kasih dan apresiasi kepada seluruh pihak yang telah berkontribusi dalam penelitian ini terutama partisipan yang telah bersedia meluangkan waktu dan tenaga sehingga penelitian ini dapat terselesaikan dengan baik.

\section{DEKLARASI POTENSI TERJADINYA KONFLIK KEPENTINGAN}

Elkanita Dwi Kriswanti dan Endah Mastuti tidak bekerja, menjadi konsultan, memiliki saham, atau menerima dana dari perusahaan atau organisasi manapun yang mungkin akan mengambil untung dari diterbitkannya naskah ini.

\section{P UST AKA ACUAN}

Azwar, S. (2017). Metode Penelitian Psikologi Edisi II. Pustaka Pelajar.

Barnard, L., Lan, W. Y., To, Y. M., Paton, V. O., \& Lai, S.-L. (2009). Measuring self-regulation in online and blended learning environments. The Internet and Higher Education, 12(1), 1-6. https://doi.org/10.1016/j.iheduc.2008.10.005

Csikszentmihalyi, M. (2014). Applications of Flow in Human Development and Education. Springer Netherlands. https://doi.org/10.1007/978-94-017-9094-9

Fakultas Psikologi Universitas Airlangga. (2020). Panduan kegiatan belajar mengajar semester gasaa 2020/2021. Fakultas Psikologi Universitas Airlangga. https://psikologi.unair.ac.id/wpcontent/uploads/2020/08/Panduan-KBM-Gasal-2020-2021.pdf

Firdaus, F. A. E. (2018). Kualitas pengetahuan mahasiswa pengguna website e-learning psyche fakultas psikologi universitas airlangga surabaya. http://repository.unair.ac.id/72397/3/JURNAL_Fis.IIP.25\%2018\%20Fir\%20k.pdf

Firman, F., \& Rahayu, S. (2020). Pembelajaran online di tengah pandemi covid-19. Indonesian Journal of Educational Science (IJES), 2(2), 81-89. https://doi.org/10.31605/ijes.v2i2.659

Guo, Z., Xiao, L., Chanyoung, S., \& Lai, Y. (2012). Flow experience and continuance intention toward online learning: An integrated framework. Thirty Third International Conference on Information Systems, Orlando 2012, 21.

Heutte, J., Fenouillet, F., Martin-Krumm, C., Boniwell, I., \& Csikszentmihalyi, M. (2016). Proposal for a conceptual evolution of the flow in education (EduFlow) model. ECPP 2016 8th European Conference on Positive Psychology, Angers, France.

Joo, Y. J., Joung, S., \& Kim, J. (2014). Structural relationships among self-regulated learning, learning flow, satisfaction, and learning persistence in cyber universities. Interactive Learning Environments, 22(6), 752-770. https://doi.org/10.1080/10494820.2012.745421 
Kementerian Sekretariat Negara RI. (2012). Undang-undang republik indonesia nomor 12 tahun 2012 tentang pendidikan tinggi. Jakarta https://jdih.setkab.go.id/PUUdoc/17624/UU0122012_Full.pdf

Kementerian Sekretariat Negara RI. (2020). KEPPRES No. 12 Tahun 2020 tentang Penetapan Bencana Nonalam Penyebaran Corona Virus Disease 2019 (COVID-19) Sebagai Bencana Nasional [JDIH BPK RI]. Jakarta. https://peraturan.bpk.go.id/Home/Details/135718/keppres-no-12-tahun-2020

Liao, L. (2006). A flow theory perspective on learner motivation and behavior in distance education. Distance Education, 27(1), 45-62. https://doi.org/10.1080/01587910600653215

Muasyaroh, H. (2018). Pengaruh penggunaan information and communications technology (ICT) dengan tujuan akademik dan non-akademik terhadap kemampuan self regulated learning pada mahasiswa. Fakultas Psikologi Universitas Airlangga, Surabaya, 206.

Patricia Aguilera-Hermida, A. (2020). College students' use and acceptance of emergency online learning due to COVID-19. International Journal of Educational Research Open, 1, 100011. https://doi.org/10.1016/j.ijedro.2020.100011

Pearce, J. M. (2005). Engaging the learner: How can the flow experience support e-learning? Dalam G. Richards (Ed.), Proceedings of E-Learn 2005-World Conference on E-Learning in Corporate, Government, Healthcare, and Higher Education (hlm. 2288-2295). Association for the Advancement of Computing in Education (AACE). https://people.eng.unimelb.edu.au/jonmp/pubs/Elearn2005.pdf

Pellas, N. (2014). The influence of computer self-efficacy, metacognitive self-regulation and self-esteem on student engagement in online learning programs: Evidence from the virtual world of Second Life. Computers in Human Behavior, 35, 157-170. https://doi.org/10.1016/j.chb.2014.02.048

Pintrich, P. R. (1995). Understanding self-regulated learning. New Directions for Teaching and Learning, 1995(63), 3-12. https://doi.org/10.1002/tl.37219956304

Pintrich, P. R. (2000). The role of goal orientation in self-regulated learning. Dalam Handbook of SelfRegulation (hlm. 451-502). Elsevier. https://doi.org/10.1016/B978-012109890-2/50043-3

Rong, W., \& Min, Y. S. (2005). The effects of learning style and flow experience on the effectiveness of elearning. Fifth IEEE International Conference on Advanced Learning Technologies (ICALT'05), 802-805. https://doi.org/10.1109/ICALT.2005.270

Shin, N. (2006). Online learner's 'flow' experience: An empirical study. British Journal of Educational Technology, 37(5), 705-720. https://doi.org/10.1111/j.1467-8535.2006.00641.x

Simonson, M., Smaldino, S., \& Zvacek, S. (2015). Teaching and Learning at Distance: Foundations of Distance Education (Sixth Edition). IAP-Information Age Publishing, Inc.

Staker, H., \& Horn, M. B. (2012). Classifying K-12 Blended Learning. https://www.christenseninstitute.org/wp-content/uploads/2013/04/Classifying-K-12blended-learning.pdf 
Wan, Q., Liu, M., Gao, B., Chang, T., \& Huang, R. (2020). The Relationship between self regulation and flow experience in online learning (a case study of global competition on design for future education). 2020 IEEE 20th International Conference on Advanced Learning Technologies (ICALT). https://doi.org/10.1109/ICALT49669.2020.00116

Zimmerman, B. J. (1990). Self-regulated learning and academic achievement: An overview. Educational Psychologist, 25(1), 3-17. https://doi.org/10.1207/s15326985ep2501_2 